\title{
G.
}

ISSN 2278 - 0211 (Online)

\section{Determinants of Financial Sector Development in Ghana}

\author{
Abubakari Najimu \\ Assistant Registrar, Department Of Academic Affairs Directorate \\ Tamale Technical University, Tamale, Ghana
}

\begin{abstract}
:
The purpose of this study is to examine the determinants of financial sector development in Ghana using annual time series data spanning from 1976 to 2017. Specifically, it investigated the determinant of financial sector development in Ghana employing five independent variables and one dependent variable using the Ordinary Least Squares (OLS). We also used models of correlation and regression. According to the regression results, the study suggests that trade openness and economic growths are key determinants of financial development in Ghana and positively boost the level of the financial sector. Once more, the results produced in this study denote that inflation and human capital are measurably critical determinants of financial development in spite of the fact that both have negative impact. However, both effects are not robust determinants since they are not significant in all the regressions. One of the most significant variables in the development of the economic industry is economic growth. To guarantee improvement of the financial sector, the Government of Ghana should execute a steady development policy that meets the prerequisites of the economy. This will encourage the advancement of financial service in the nation.
\end{abstract}

Keywords: Financial, economic, development, Ghana, growth

\section{Introduction}

Financial markets and institutions performs relevant role in the economic growth process, especially through their job in apportioning fund to profitable exercises. This role has been all around inquired about and archived in the exact writing, utilizing an assortment of econometric strategies. Very much looked into and reported in the experimental writing, utilizing an assortment of econometric systems. All things considered, this paper proposes that well-working financial institutions and markets move forward with long-term economic growth (Beck et al., 2000). Anyway, a fascinating investigation continues why have such a large of countries remained underdeveloped if economic growth is so helpful for growth? More generally, why have some countries developed well-working markets and organizations in the economic industry, while others did not? Given the nexus between finance and economic development, understanding the elements that could clarify the difference in the economic growth dimension is essential. Approach estimates, for example, financial and exchange trade liberalization have authoritatively been announced as determinants of financial development. Liberating the monetary framework from government intercession permits an increasingly productive allocation of resource by different financial operators while liberalization trade decreases the intensity of intrigue parties who captures legislators to shape arrangements or put measures in place to support them do away with things which obstructs financial development. Accordingly, the progression procedure decreases wastefulness, improves transparency and ensures a focused situation which is helpful for the economy in general (Seetanah et al., 2010).

With the assistance of the International Monetary Fund (IMF) and the World Bank, economic sector progress in Ghana began in the early 1980s under the Financial Sector Adjustment Program (FINSAP) with the reconstruction of distressed banks and the reorganization of non-performing assets to restore productivity and viability to banks. The program fixes prices, initiates structural modifications, including economic and fiscal operations, as well as privatizations including banks (Bawumia, 2010). Nation-specific concentrations that have dared to feature the short-run and long-run determinants of economic growth are subtle. More specifically, there are not many observational studies here in Ghana to fill in as a policymakers ' guide (Acheampong, 2010; Adam and Tweneboah, 2009), and this has prompted this review. Given this basis, the determinants of economic growth in Ghana should be carefully checked as it is discovered that financial markets have taken on an important role in promoting financial growth. The motive behind this inquiry is therefore to explore the determinants of Ghana's economic growth.

According to Khan and Senhadji (2000), the positive link between financial development and economic growth is in one sense fairly obvious as observed in the general case of developed economies. There has been an argument that, a well-functioning financial sector is a pre-requisite for the efficient allocation of resources and exploitation of the potential growth of an economy. However, there exist divergent views on existing literatures on how and to what extent financial 
development affects economic growth. Some researchers have the view that, financial development leads to economic growth. To these researcher's financial development is critical to growth (Schumpeter, 1911; Goldsmith, 1969; McKinnon, 1973; Shaw, 1973; Bencivenga and Smith 1991; King and Levine 1993;; Christopoulos and Tsionas 2004). Another group of researchers also asserts that, finance is a handmaiden to industry and commerce (Robinson, 1952; Lucas, 1988; Stern, 1989; Demetriades and Hussein, 1996 and Arestis and Demetriades, 1997). Their argument was that, finance is demandled and as such the lack of financial development is simply a manifestation of the lack of demand for financial services (Xu 2000). Other group of researchers is of the view that, there exists a bidirectional relationship between financial sector development and economic growth (Wood, 1993; Demetriades and Hussein 1996; Akinboade1998; Luintel and Khan 1999; Rousseau and Vuthipadadorn 2005; Apergis et al. 2007; Siaw and Frimpong 2010). Adusei (2013) believes that, there is a direction with negative effect between finance and growth. They suggested that, finance has negative impacts on economic growth and as such economic policies should be geared towards repressing the financial sector. Moreover, various proxies were adopted by various researchers in their studies. Adu et al., (2013) argue that the choice of the measure of financial development matter. In their study, they found that, the growth effect of financial development is sensitive to the choice of proxy. The few studies that have been conducted on Ghana with respect to financial development and economic growth have all failed to account for the effects of stock market on the theme (Quartey 1997, 2005; Quartey and Prah 2008; Siaw and Frimpong 2010; Adu et al. 2013; Adusei 2013). According to Levine (1991), stock markets accelerate growth by (1) facilitating the ability to trade ownership of firms without disrupting the productive processes occurring within the firms and (2) allowing agents to diversify portfolios. In opposition to this finding, Osamwonyi and Kasimu (2013) asserted that, there is no causality link between stock market development and economic growth in the case of Ghana and Nigeria. This calls for some empirical analysis at country level to determine whether financial development leads to growth or vice versa. In addition, the Economic Recovery Program instituted in Ghana in the 1980's has so far resulted in some positive development in Ghana's financial sector, investment and economic growth accelerated, but the issue of whether the financial sector development induced the growth in the economic activities remains unanswered. Whereas Siaw and Frimpong (2010) are of the view that finance induces growth in Ghana, Adusei (2013) on the other hand believes that finance has no effect on growth. Such divergent views in findings call for additional research to help resolve this issue at hand.

With regard to the above studies, majority of the studies have looked at the impact of financial development on economic growth without examining the determinants of financial development. More so, those studies that examined the determinants of financial development did not study for that of Ghana. They used panel data and grouped all the countries together making it difficult to know the determinants for financial development for only Ghana. One of those studies that grouped all the countries is the work of Ibrahim and Sare (2018). However, using of their study, it is particularly impossible to examine the unique factors affecting financial sector for only Ghana given the different situations of countries in Africa.

The rest of the study is organized as follows: the next section presents the literature review while Section 3 outlines our methodology. Section 4 discusses the empirical findings while Section 5 concludes the study.

\section{Literature Review}

Financial development is part of the private sector development strategy to arouse economic growth and reduce poverty. The financial sector is the set of institutions, instruments, and market. Good economic foundations and markets stimulate long-term monetary growth (Beck et al., 2000). By and by, a propelling investigation continues why have so many countries stayed underdeveloped if economic growth is so helpful for growth? More generally, why have some countries developed well-functioning financial markets and institutions, while others did not? Given the nexus of monetary growth, understanding the aspects that could clarify the difference in the financial enhancement dimension is fundamental. For instance, policy measures, economic and trade liberalization have been declared authoritative as determinants of financial development. Liberating the budgetary structure from public intercession allows distinct monetary experts to gradually allocate funds while liberalization trade diminishes the strength of interest groups capturing politicians to form policies to promote them that hinder economic growth. In this ability, the process of progression reduces wastefulness, increases transparency and guarantees a centered domain that is beneficial to the economy as a whole (Seetanah et al., 2010). Financial growth in Ghana began in the early 1980s under the Financial Sector Adjustment Program (FINSAP) with the assistance of the International Monetary Fund (IMF) and the World Bank, rebuilding distressed banks and tidying up non-performing benefits to restore banks to productivity and practicality. The program fixes prices, initiates structural modifications, including economic and fiscal operations, as well as privatizations including banks (Bawumia, 2010). It is subtle to study that has dared to feature the short-run and long-run determinants of economic growth at national interest points. More specifically, there are not many observational exams here in Ghana to fill in as a guide for arrangement manufacturers (Acheampong, 2010; Adam and Tweneboah, 2009), and this has persuaded this inquiry. Given this basis, the determinants of economic growth in Ghana should be carefully evaluated as it is discovered that financial markets have taken on an important role in promoting economic growth. The reason for this review is therefore to investigate the determinants of Ghana's economic growth.

\subsection{Theoretical and Empirical Literature}

Ronald McKinnon (1973) and Edward Shaw (1973) were the first to explain the thought of financial restraint. While hypothetically an economy with an effective financial framework can accomplish development and improvement through productive capital distribution, McKinnon and Shaw contend that generally, numerous nations, including developed ones yet particularly developing ones, have limited challenge in the financial sector with government 
mediations and guidelines. As per their contention, a repressed financial sector discourages both savings and investment in light of the fact that the rates of return are lower than what could be acquired in an aggressive market. In such a framework financial intermediaries don't World Economy Financial Repression to work at their full limit and neglect to channel savings into venture proficiently, in this way hindering the improvement of the in general economic system.

Ibrahim and Sare (2018) argue that financial development goes beyond the traditional measure. They focus on the interactive effect of trade openness and human capital in explaining country's financial sector development.

Their examination is titled towards distinguishing the variables clarifying the distinctions in financial sector development. The discourse consolidated the interaction between the load of human capital and trade openness in clarifying financial development in Africa, a continent with moderately under-developed financial sector where domestic financial are to a great extent bank-based. In fact, whiles trade openness grant improves financial development by taking into account outer finance, the productive financial intermediation that join trade openness is conceivable once economies have high human capital stock to convey and interest for improve financial sector development. At the end of the day, when nations open their economies to trade remotely, domestic human capital stock ought to be sufficiently improved to interest for better financial intermediation and financial services all of which upgrades nations domestic financial sectors. They also estimated that while both greater levels of openness and aggregation of human capital could enhance economic growth separately, closed countries could profit more by opening up their economies to trade and building up their capital stock through extended access to training. Evidence from the inquiry suggests that while human capital has a strong effect on economic enhancement, trade openness gives personal credit more than national credit. In this situation, the interactive conditions of openness and capital are closely linked to economic growth. Their results indicate that the least open nations to trade are more likely to benefit from the growth of their banking sector. Accumulations of human capital and trade openness that can be replaced in affecting economic growth in Africa are important.

Like other piece of the world, Ghana isn't forgotten on the examination on the financial development. Different looks into have added to the writing on financial development, some of which are relevant for reviewing. Baltagi et al. (2007), utilizing panel data procedures and yearly information, demonstrated that trade openness and financial openness together with economic organizations decides the financial development uniqueness crosswise over nations. Their outcomes demonstrated that nations that are least open can profit incredibly as far as financial development on the off chance that they open either their trade or capital records. These nations can have considerably more advantages in the event that they open both, however opening just a solitary one can in any case bring about development in the banking sector. Then again, nations that are most open advantage the least from added openness.

Dehesa et al. (2007) provided an accurate cross-country examination of the financial deepening determinants using a board of 120 countries somewhere in the 1997 and 2004 range. Their review suggested that a need be provided to managing inflation in a high inflation situation and reducing macroeconomic instability.

The interrelationship between economic growth and poverty reduction in Ghana was essentially examined by Quartey (2005). This was completed using World Development Indicators time-series data from 1970-2001.The primary findings of his inquiries were, first, that despite the reality that the growth of the economic industry is not causing Granger savings mobilization in Ghana, it is causing inflation to decline; and second, that savings are causing poverty to decline in Ghana. Similarly, the effect of the growth of the economic industry on poverty reduction is certainly yet insignificant. This is due to the manner in which Ghana's financial intermediaries have not adequately diverted resources to the pro-poor areas of the economy owing to government deficit financing, high default rate, lack of collateral and lack of suitable company suggestions. Another intriguing finding from his review was that there was a long-term link between the growth of the economic industry and the reduction of poverty. Adam and Tweneboah (2008) used a multivariate model of cointegration and error modification to examine the impact of FDI on the growth of Ghana's stock market. Results from their inquiry have shown that foreign direct investment, nominal exchange rate and stock market growth in Ghana have a long-term connection. Their examination suggests that foreign direct investment shocks have an impact on Ghana's stock market. In the environment of the economic industry episode of Ghana, Acheampong (2007) evaluated the McKinnonShaw proposal. Specifically, he examined the nexus of savings and real interest rate, investment and real interest rate, and nexus of investment and economic development using quarterly data from 1988 to 2004 and the VAR policy. His result vindicated the nexus of savings and real interest rate, investment and real interest rate nexus, and the nexus of investment and economic development when applied to long-term research. In any event, the causality test endorsed the true nexus of interest and savings, investment and economic growth and an inverted causality running from economic development to savings.

Ibrahim and Sare (2018) contend that financial development goes past the traditional measure. They center on the intuitive impact of trade openness and human capital in clarifying nation's financial sector development. Their examination is titled towards recognizing the variables clarifying the distinctions in financial sector development. The dialog fused the interaction between the stock of human capital and trade openness in clarifying financial development in Africa, a continent with moderately underdeveloped financial sector where domestic financial are to a great extent bankbased.

Of course, while trade openness licensing enhances economic growth by taking internal funds into consideration, the efficient economic intermediation that joins trade openness is conceivable once countries have elevated human capital stocks to supply and demand to enhance the growth of the economic industry. Ultimately, when countries open their economies to external trade, national human capital stock should be adequately enhanced to demand better economic intermediation and financial services, all of which upgrade domestic financial sector. They also conjectured that while greater levels of openness and accumulation of human capital could individually lead to economic growth, shut-down countries could profit more by opening up their economies to trade and building up their capital stock through extended 
access to training. Evidence from the inquiry suggests that while human capital has a strong effect on economic growth, trade openness strongly gives personal credit more than national credit. Fundamentally recognized with economic growth are the intuitive conditions of openness and capital for this scenario. Their findings suggest that the least tradable countries continue to profit more from the growth of their banking sector. Accumulation of human capital and trade openness can be replaced by a critical impact on economic growth in Africa. Past examinations of legislation-the writing of funds have neglected to I draw on the critical work of law in financial growth in the context of creating legal frameworks in SSA just as (ii) evaluate how legal origin clarifies cross-country contrasts in economic volatility. In addition, how law shaping viability or cut-off information sharing in growth volatility is not fully explored. The purpose of this review was to I examine whether cross-country differences in financial development and economic volatility can be explained by differences in SSA legal origins and (ii) how legal origin interacts with data sharing in impacting growth volatility.

The different observational and hypothetical dialogs above on financial development in Ghana demonstrate the varying perspectives on different analysts on the subject under thought. It tends to be noticed that the outcomes emerging from the diverse contentions are because of the intermediary, pointers and information utilized in breaking down the result of the examination. The contention from the determinant of financial development sector in Ghana is as yet intricate. These current holes require the legitimacy of further examination on Ghana and thus the need to embrace this undertaking to put this discussion under appropriate setting.

\section{Data Description and Empirical Strategy}

\subsection{Data Description}

This section discusses the specific data or variables used for this study. There are two types of variables used under this study, namely; dependent variables and independent variables. The data are discussed below:

\subsubsection{Private Sector Credit}

It is a qualitative metric and probably the most important indicator of banking growth as it intermediates the degree to which new companies have opportunities to obtain finance from the banking industry (Baltagi et al., 2009). This economic development intermediary that represents credit advanced to the private sector captures the use and designation of resources for exercises that are gradually profitable and lucrative. Private sector credit has been commonly used in writing as an indicator of finance (see Baltagi et al., 2009; Beck et al., 2003; Ibrahim and Alagidede, 2017a, b; Levine, 2005; Levine et al., 2000; Adeniyi et al., 2015)

\subsubsection{Inflation}

World Bank (2011) characterized inflation as "a supported increment in the general value dimension of costs for merchandise and services. It is estimated as a rate change in the expense to the normal shopper of gaining a fixed basket of merchandise and services at indicated interims, for example, yearly, month to month, day by day and so forth." Inflation is relied upon to be contrarily connected to financial development. Inflation is utilized to represent macroeconomic instability.

\subsubsection{Real GDP Per Capita}

This is GDP per capita which is estimated as the proportion of total national output to add up to populace and is an indicator of a nation's expectation for everyday comforts. Information is in constant local currency which infers the arrangements are in genuine terms. A higher living standard comforts is gainful for improve access to financial services. It is utilized to mean economic development.

\subsubsection{Legal Origin}

Legal origin is dummy variable where pre-adoption thus, 1976 to 1991 takes the value zero and post - adoption thus 1992 to 2017 taking the value 1.

\subsubsection{Trade Openness}

This is the totality of merchandise and service exports and imports estimated as a Gross Domestic Product (GDP) level. With the advent of globalization, more countries are gradually grasping trade liberalization that has been experimentally demonstrated to have positive economic growth outcomes.

\subsubsection{Human Capital}

It is a stock of knowledge, habits, social and identity qualities, including creativity, exemplified in the capacity to perform work to create economic value. Human capital hypothesis is intently connected with the investigation of human resource management as found in the act of business organization and macroeconomics. This investigation utilizes the secondary school enrolment rates as a level of gross to intermediary human capital stock.

\subsection{Empirical Strategy}

This section deals with the empirical strategy of the study; this study focuses on one dependent variable and five independent variables as, discussed in section 3.1 above. This section actually talks about the estimation approach using the ordinary least squares.

Mathematically, we denote the equation by; 
$F S D_{t}=f\left(I N F_{t}, R G D P_{t}, L O_{t}, T O_{t}, H C_{t}\right)$.

3.1

Where; FSD is financial sector development GDP is real GDP per capita;

LO is legal origin; TO is trade openness; $\mathrm{HC}$ is human capital; $\mathrm{t}$ is time index

Therefore, we re-write the equation (3.1) as;

$F S D_{t}=\beta_{0}+\beta_{1} I N F_{t}+\beta_{2} G D P_{t}+\beta_{3} L O_{t}+\beta_{4} T O_{t}+\beta_{5} H C_{t}+\epsilon_{t} 3.2$

From equation (3.2), $\beta_{0}$ is constant, where the coefficients $\beta_{1}, \beta_{2}, \beta_{3}, \beta_{4}$ and $\beta_{5}$ are the parameters of the respective variables while $\epsilon$ is the error term.

From the equation, if inflation is less than zero it negatively affects FSD and in the other way round when it is greater than zero it positively affects FSD. If GDP $<0$ it negatively affects FSD otherwise positively affect FSD if $>0$. If $\mathrm{LO}<$ 0 it negatively affects FSD otherwise positively affect FSD if $>0$. If TO $<0$ it negatively affects FSD otherwise positively affect FSD if $>0$. If $\mathrm{HC}<0$ it negatively affects FSD otherwise positively affects FSD if $\mathrm{HC}>0$.

The study builds the following null and alternate hypotheses:

Null hypothesis: $H_{0}: \beta_{i}=0$

Alternate hypothesis: $H_{0}: \beta_{i} \neq 0$

By not rejecting the null hypothesis for a particular variable suggests that the variable in question does not have critical impact on financial development and by rejecting the null hypothesis implies that, that variable has significant impact on financial development.

This chapter reviews the important methodological process in gathering all the appropriate data required for the study. In conducting this research, we used the annual time series data obtained from the World Development Indicators of the World Bank. The choice of data is based on the data availability for our variables.

\section{Findings and Discussions}

This chapter is divided into various sections that reviews the findings and discussions made so far. Section 4.0 deals with descriptive statistics including the correlation coefficients, Section 4.1 conclusion the study with key policy implication.

The study conducted the descriptive statistics of the relevant variables involved. Table 4.1 illustrates vividly these statistics.

\begin{tabular}{|c|c|c|c|c|c|c|}
\hline & PC & EG & INF & TO & HC & LO \\
\hline Mean & 8.695 & $1,046.06$ & 32.007 & 58.746 & 42.904 & 0.619 \\
\hline Standard Deviation & 5.251 & 295.791 & 28.939 & 29.674 & 10.961 & 0.491 \\
\hline Coefficient of variation & 0.604 & 0.283 & 0.904 & 0.505 & 0.255 & 0.793 \\
\hline Skewness & 0.093 & 1.14 & 1.971 & -0.061 & 1.53 & -0.49 \\
\hline Kurtosis & 1.336 & 3.065 & 6.308 & 2.031 & 3.962 & 1.24 \\
\hline Minimum & 1.542 & 701.535 & 7.126 & 6.32 & 33.871 & 0 \\
\hline Maximum & 15.882 & 1755.605 & 122.874 & 116.048 & 69.953 & 1 \\
\hline Observation & 42 & 42 & 42 & 42 & 42 & 42 \\
\hline
\end{tabular}

Table 1: Descriptive Statistics

Note: PC=Private Credit; EG=Economic Growth; INF=Inflation;

$\mathrm{O}=$ Trade Openness; HC=Human Capital

$\mathrm{LO}=$ Legal Origin

From Table 4.1, the mean value of private credit is $8.695 \%$ with a standard deviation of $5.251 \%$. The low average value of private credit confirms the relatively under-developed nature of the financial sector development of Ghana. The average Real GDP per capita over the sample period is US $\$ 1,046.059$ hence reaffirming the low income level status of the country. While inflation averages $32 \%$, the mean value of trade openness is $58.75 \%$ with corresponding standard deviation of 28.939 and 29.674 respectively. With regard to human capital, the mean value of secondary school enrolment rate is $42.904 \%$ of gross. Also most of the variables show positive sign of skewness and therefore its graphical representation will be skewed to the right. With respect to the table above it can observed that none of the variables is normally distributed given the values of skewness and kurtosis. The coefficient of variation which is processed as the proportion of standard deviation to mean estimates the relative dispersion of the variables. This suggests the higher the coefficient of variation, the more volatile the instability consequently permitting the immediate examination of the general unpredictability of our arrangement given the distinctions in means. Among all the variables, economic growth is the most volatile followed by trade openness and then inflation. Human capital is the least volatile while legal origin generally shows the lowest volatility among all the variables.

\subsection{Correlation Coefficients}

This section presents the results of the correlation coefficients which shows the relationship between the variables used in this study. Table 4.2 shows the correlation matrix. 


\begin{tabular}{|c|c|c|c|c|c|c|}
\hline & PC & EG & INF & TO & HC & LO \\
\hline PC & 1.000 & & & & & \\
\hline EG & 0.796 & 1.000 & & & & \\
\hline INF & -0.575 & -0.424 & 1.000 & & & \\
\hline TO & 0.816 & 0.468 & -0.585 & 1.000 & & \\
\hline HC & 0.618 & 0.938 & -0.316 & 0.217 & 1.000 & 1.000 \\
\hline LO & 0.801 & 0.593 & -0.558 & 0.846 & 0.381 & \\
\hline
\end{tabular}

Table 2: Correlation Matrix

Note: $\mathrm{PC}=$ private credit; $\mathrm{EG}=\mathrm{economic}$ growth; INF=inflation;

$\mathrm{TO}=$ trade openness; $\mathrm{HC}=$ human capital

$\mathrm{LO}=$ legal origin

From Table 4.2, private credit is positively correlated with all the variables economic growth, trade openness, human capital, legal origin except inflation. More so, its correlation is strongest with trade openness followed by legal origin and lowest with inflation. Economic growth is positively correlated with all the variables trade openness, human capital, and legal origin except inflation. Inflation is negatively correlated with all the variables trade openness, human capital, and legal origin. Legal origin is positively correlated to all the variables with the exception of inflation. This notwithstanding, its correlation with human capital is weak.

\subsection{Empirical Findings}

This section presents findings of the regression results based on the OLS approach. The study estimates five regressions/ models given the five independent variables where the repressors' are introduced in succession in order to examine the robustness. Table 4.3 presents the results.

\begin{tabular}{|c|c|c|c|c|c|}
\hline & 1 & 2 & 3 & 4 & 5 \\
\hline Constant & $\begin{array}{l}12.038 \\
(1.006) \\
{[11.96]} \\
\{0.000\}\end{array}$ & $\begin{array}{c}-2.138 \\
(2.137) \\
{[-1.00]} \\
\{0.323\}\end{array}$ & $\begin{array}{c}-2.457 \\
(1.728) \\
{[-1.42]} \\
\{0.163\}\end{array}$ & $\begin{array}{c}-6.561 \\
(1.580) \\
{[-4.15]} \\
\{0.000\}\end{array}$ & $\begin{array}{c}-6.277 \\
(1.856) \\
{[-3.38]} \\
\{0.002\}\end{array}$ \\
\hline INF & $\begin{array}{c}-0.104 \\
(0.023) \\
{[-4.45]} \\
\{0.000\}\end{array}$ & $\begin{array}{c}-0.052 \\
(0.017) \\
{[-3.00]} \\
\{0.005\} \\
\end{array}$ & $\begin{array}{c}-0.021 \\
(0.015) \\
{[-1.41]} \\
\{0.167\}\end{array}$ & $\begin{array}{c}-0.004 \\
(0.012) \\
{[-0.38]} \\
\{0.703\}\end{array}$ & $\begin{array}{c}-0.005 \\
(0.012) \\
{[-0.42]} \\
\{0.675\}\end{array}$ \\
\hline EG & & $\begin{array}{c}0.011 \\
(0.001) \\
{[6.99]} \\
\{0.000\}\end{array}$ & $\begin{array}{c}0.008 \\
(0.001) \\
{[5.41]} \\
\{0.000\}\end{array}$ & $\begin{array}{c}0.009 \\
(0.001) \\
{[7.47]} \\
\{0.000\}\end{array}$ & $\begin{array}{c}0.010 \\
(0.004) \\
{[2.22]} \\
\{0.033\}\end{array}$ \\
\hline LO & & & $\begin{array}{c}4.807 \\
(1.031) \\
{[4.66]} \\
\{0.000\}\end{array}$ & $\begin{array}{c}0.220 \\
(1.220) \\
{[0.18]} \\
\{0.858\}\end{array}$ & $\begin{array}{c}0.166 \\
(1.248) \\
{[0.13]} \\
\{0.894\}\end{array}$ \\
\hline TO & & & & $\begin{array}{c}0.095 \\
(0.019) \\
{[5.01]} \\
\{0.000\}\end{array}$ & $\begin{array}{c}0.092 \\
(0.022) \\
{[4.15]} \\
\{0.000\}\end{array}$ \\
\hline $\mathrm{HC}$ & & & & & $\begin{array}{c}-.034 \\
(.115) \\
{[-0.30]} \\
\{0.764\}\end{array}$ \\
\hline \multicolumn{6}{|l|}{ Diagnostics: } \\
\hline R-Squared & 0.331 & 0.703 & 0.811 & 0.887 & 0.887 \\
\hline $\begin{array}{l}\text { Adjusted R- } \\
\text { squared }\end{array}$ & 0.315 & 0.688 & 0.796 & 0.875 & 0.872 \\
\hline F-statistic & 19.82 & 46.25 & 54.40 & 73.03 & 57.01 \\
\hline $\mathrm{p}$-value & 0.000 & 0.000 & 0.000 & 0.000 & 0.000 \\
\hline VIF & 1.494 & 3.367 & 8.403 & 8.849 & 8.849 \\
\hline
\end{tabular}

Table 3: Determinants of Financial Development in Ghana

Notes: Values In ( ), [ ], \{ \} Respectively Represent Standard Error,

T-Statistics and P-Values VIF = Variance Inflation Factor

Beginning with model 1, the study finds that, inflation has a negative effect on private credit. An increase in inflation will decrease the private credit. More specifically, a $1 \%$ increase in inflation will lead to $0.104 \%$ decrease in private credit and $1 \%$ decrease in inflation will also lead to $0.104 \%$ increase in private credit. The effect of inflation in model 1 is significant at $1 \%$ since the p-value is less than 0.01 . The negative relationship between inflation and financial development implies that, higher inflation does not promote domestic financial sector. Indeed, higher inflation erodes 
savings and for that matter, less income is saved at financial sector hence less funds are available for the financial sector players to use to develop. Thus, inflationary pressures restrict financial sector development in Ghana. In other words, higher macroeconomic instability decreases financial institutions appetite offer credit to private sector players. This finding is consistent with Ibrahim and Sare's (2018) study.

In model 2 involves inflation and economic growth. Inflation maintains its negative and significant effect on private credit where $1 \%$ increase in inflation leads to $0.052 \%$ decrease in private credit and $1 \%$ decrease in inflation results in $0.052 \%$ increase in private credit. With regard to economic growth, our findings show that, economic growth has a positive effect on private credit. An increase in economic growth will increase private credit, therefore $1 \%$ increase in economic growth will lead to $0.011 \%$ increase in private credit and $1 \%$ decrease in economic growth will also lead to $0.011 \%$ decrease in private credit. Given the p-value, the effect of economic growth in model 2 is significant at $1 \%$. Consistent with Ibrahim and Sare (2018), increase in real GDP per capita increase people's demand for improved financial services which eventually increases domestic financial development.

With regard to model 3 where legal origin is included into the regression, our findings show that, relative to the period before the adoption of the 1992 Constitution, legal origin and adoption of the Constitution is positively associated with financial development. This effect is statistically significant at $1 \%$.Relatively to the pre-adoption of the Constitution, there is a positive relationship between post-adoption and financial sector development. Thus, the adoption of the country's legal constitution positively affected the country's financial sector development by streamlining the legal system protecting private sector players and this is expected to improve financial sector development. Inflation has a negative effect on private credit with a coefficient of 0.021 . However, compared to models 1 and 2, the effect of inflation is not significant at conventional levels. Economic growth has a positive and significant effect on private credit. An increase in economic growth will increase private credit, therefore $1 \%$ increase in economic growth will lead to $0.008 \%$ increase in private credit and $1 \%$ decrease in economic growth will also lead to $0.008 \%$ decrease in financial development.

Model 4 consists of inflation, economic growth, legal origin and trade openness. Inflation maintains it negative but has insignificant effect on financial development where $1 \%$ increase in inflation leads to $0.004 \%$ decrease in financial development and $1 \%$ decrease in inflation results in $0.004 \%$ increase in financial development. Economic growth also maintains its positive and significant effect on financial development. An increase in economic growth will increase financial development, therefore $1 \%$ increase in economic growth will lead to $0.009 \%$ increase in financial development and $1 \%$ decrease in economic growth will also lead to $0.009 \%$ decrease in financial development. With regard, to legal origin, our findings show that, relative to the period before the adoption of the 1992 Constitution, legal origin and adoption of the Constitution still maintains its positive effect although the effect is statistically insignificant. Relatively to the pre-adoption of the Constitution, there is a positive relationship between post-adoption and financial sector development. Trade openness has a positive effect on financial development. An increase in trade openness will lead to an increase in financial development, therefore $1 \%$ increase in trade openness will lead to $0.095 \%$ increase in financial development and $1 \%$ decrease in trade openness will also lead to $0.095 \%$ decrease in financial development. Trade openness is significant at $1 \%$.

This model includes inflation, economic growth, legal origin, trade openness and human capital. Inflation maintains its negative sign but has insignificant effect on financial development. An increase in inflation will decrease the financial development, more specifically, $1 \%$ increase in inflation will lead to $0.005 \%$ decrease in financial development and $1 \%$ decrease in inflation will also lead to $0.005 \%$ increase in financial development. Economic growth maintains its positive and significant effect on financial development, therefore 1\% increase in economic growth will lead to $0.010 \%$ increase in financial development and 1\% decrease in economic growth will also lead to $0.010 \%$ decrease in financial development. Trade openness also maintains its positive and significant effect on financial development. An increase in trade openness will lead to an increase in private credit, therefore $1 \%$ increase in trade openness will lead to $0.092 \%$ increase in financial development and $1 \%$ decrease in trade openness will also lead to $0.092 \%$ decrease in financial development. Human Capital has a negative effect on financial development. An increase in human capital will lead to a decrease in financial development, therefore $1 \%$ increase in human capital will lead to $0.034 \%$ decrease in financial development and $1 \%$ decrease in human capital will also lead to $0.034 \%$ in private credit. Given the p-value, the effect of human capital in model 5 is insignificant. Human capital is insignificant and has a negative effect on financial development because of the low level of human capital accumulation in Ghana.

\section{Conclusion and Policy Implications}

In accordance with the regression result, the examination has demonstrated that trade openness and economic growth are factually significant determinants of financial development in Ghana and decidedly drive the dimension of financial sector. Once more, the outcomes exhibited in this investigation suggest that expansion and human capital are factually significant determinants of financial development although both have negative impact. However, both effects are not robust determinants since they are not significant in all the regressions.

The political consequences are that; developing countries governments whose economies are not yet open to universal trade presently have a motivating force to open their fringes to boost their economic growth enhancement.In particular, Ghana government requires enhancing its exchange in order to take into consideration a well-working economic industry with all its advantages. Another, Ghana's government requires putting in place steps to maintain the Ghanaian economy's low inflation rate. This is on the grounds that poor macroeconomic performance just conveys less impact to a developing economy, that is, high disparity, erratic development, and above all, a restrictive financial sector. With regard to legal origin, relatively to the pre-adoption of the Constitution, there is a positive relationship between postadoption and financial sector development. Thus, the adoption of the country's legal constitution positively affected the 
country's financial sector development by streamlining the legal system protecting private sector players and this is expected to improve financial sector development. Our findings largely suggest that, only economic growth and trade openness robustness matter for domestic financial development.

\section{References}

i. Abu-Bader, S. and Abu-Qarn, A. M. (2008). -Financial development and economic growth: empirical evidence from MENA countries\|. Review of Development Economics 12. 803-817.

ii. Adam, M. and Tweneboah, G. (2009), “Foreign direct investment and stock market development: Ghana's evidence", international Research Journal of Finance and Economics, Vol, No. 2, pp. 14502887.

iii. Adu, G., Marbuah, G., and Mensah, J.T. (2013). -Financial Development and Economic Growth in Ghana: Does the measure of financial development matter? // Review of Development Finance, 3, pp. 192-203.

iv. Ang, J.B. (2008), "Are financial sector policies effective in deepening the Malaysian financial system?", Contemporary Economic policy, Vol, 26No. 4, pp. 623-635.

v. Aryeetey, E. (1994) Financial Integration and Development in Sub-Saharan Africa: A Study of Informal Finance in Ghana. London: ODI Working Paper No. 78.

vi. Baltagi, B.H., Demetriades, P.O. and Law, H.S. (2007), "Financial development, openness and institutions: Evidence from panel data", Journal of Development Economics, Vol. 89 No.2, pp. 285-296.

vii. Bawumia, M. (2007), Banking in Ghana in the Last 50 Years-Challenges and Prospects, A Keynote Address at the Launch of Ghana Banking Awards, M-Plaza, Accra.

viii. Bawumia, M. (2010), "Monetary policy and financial sector reform in Africa: Ghana's experience", Accra, Combert, Impressions.

ix. Beck, T. and Levine, R. (2003), "Legal Institutions and financial development", Journal of financial Economics.

x. Ghirmay T. (2004). - Financial Development and Economic Growth in Sub-Saharan African Countries: Evidence from Time Series Analysis, African Development Review, 16(3).

xi. Giorgio, D.G. (1999), "Financial development and reserve requirements”, Journal of Banking and Finance, Vol. 23 No. 7, pp. 1031-1041.

xii. International Monetary Fund (2007), Denmark: Financial Sector Assessment Program Technical NoteCompetition in the Banking Sector, IMF Country Report No. 07/ 122.

xiii. International Monetary Fund (IMF) (2011), "Ghana: Financial system stability assessment update”, country report, IMF, Washington, D.C.

xiv. Ibrahim, M., and Sare, Y.A., (2018), "Determinants of financial development in Africa; How robust is the interactive effect of trade openness and human capital? Economic analysis and policy, 60, 18-26.

xv. Khan, M.A., 2008. ||Financial development and economic growth in Pakistan: evidence based on Autoregressive Distributed Lag (ARDL) approach\|. South Asia Economic Journal 9 (2), 375-391.

xvi. Khan, S.M., Senhadji, A.S., (2000). -Financial Development and Economic Growth: An Overview\|. IMF Working Paper. International Monetary Fund, Washington, 5-14.

xvii. King, R. G. and Levine, R. (1993), "Finance and growth: Schumpeter might be right”, The Quarterly Journal of Economics, Vol. 108 No. 3, pp. 717-737.

xviii. Levine, R. (1998). - Financial Development and Economic Growth; Views and Agenda\|.

xix. Journal of Economic Literature, Vol.35, pp.31-77.

xx. Levine, R. (2004). - Finance and growth: theory and evidence\|, NBER Working.

xxi. Levine, R. and Zervos, S. (1998) Stock markets, banks, and economic growth. American Journal of Economics, 22310.

xxii. Quartey, P. (2005), “Financial sector development, savings mobilization and poverty reduction in Ghana”, Journal of international development, 17(8).

xxiii. Seetanah, B., Padachi, K., Hosany, J. and Seetanah, B. (2010), "Determinants of financial development: The case of Mauritius", Finance and Corporate Governance Conference 2011Paper, available at: http:/ / dx.doi.org/ 10.2139/ ssrn.1724404.

xxiv. Seetanah, B., Ramessur S. and Rojid, S. (2009), "Financial development and economic growth: New evidence from a sample of Island economies", Journal of Economic Studies, Vol. 36 No. 2, pp. 124-134. 